\title{
Monetization of Workers Fringe Benefits: The Journey so far in Nigeria Federal Civil Service
}

\author{
Joseph C. Okoye ${ }^{1}$, Rosemary O. Anazodo ${ }^{1}$, Edwin M. Izueke ${ }^{2} \&$ Sunday C. Eze ${ }^{3}$ \\ ${ }^{1}$ Public Administration Department, Nnamdi Azikiwe University, Awka, Anambra, Nigeria \\ ${ }^{2}$ Public Administration Department, University of Nigeria, Nsukka, Nigeria \\ ${ }^{3}$ Business and Management Research Institute, University of Bedfordshire, UK \\ Correspondence: Sunday C. Eze, Business and Management Research Institute, University of Bedfordshire, UK. \\ Tel: 44-123-440-0400. E-mail: eze.Sunday2010@gmail.com
}

Received: September 20, 2011 Accepted: October 8, 2011 Online Published: October 18, 2012

doi:10.5539/par.v1n1p50 URL: http://dx.doi.org/10.5539/par.v1n1p50

\begin{abstract}
This study appraises the monetization of workers fringe benefit in Nigeria's federal Civil Service with a view to identifying the problem areas. Data collected through questionnaire were analyzed using Chi-square. The findings revealed that the monetization policy has reduced the running cost of federal government of Nigeria, somehow bettered the lots of workers, greatly favored the ruling elites, and generated some unintended consequences due to the reversal of some aspects during implementation. However, in order to ensure equity in the distribution of benefits of the policy, it is recommended that payment of housing and furniture allowances should be en bloc and direct method to be adopted in the implementation to curb reversal of the contents of the policy. More so, state and local governments in Nigeria and under-developed and developing countries are to adopt the policy to their civil service for efficiency and cost effectiveness.
\end{abstract}

Keywords: monetization, benefits, cost, elite theory, efficiency, effectiveness

\section{Introduction}

The long military rule in Nigerian left its toll on almost every aspect of the Nigerian life. Social infrastructure, economy, public service, rural development, etc. were adversely affected. Onu (2007) observed that in Nigeria, there was total infrastructural decay, the economy was in shambles, the public service was inefficient and corrupt, there were wastages in government, etc.

An array of hope came in 1999, when a new democratic government came to power. In reaction to the general hash prevailing conditions in the country, president Obasanjo's administration embraced reforms in all sectors of the economy. Such reforms included the local government's reform, re-capitalization of banks, trade liberalization, private sector development, anti-corruption, institutional reforms, and the public sector reforms.

Of all the reforms, the public service reform is the most central. This is because as Philips (1988) observed, the public service is the major instrument used by government to implement its policies. These policies of government included all those reforms mentioned above. He further said that as a human instrument used to manage a human society, the performance of the public service can be ignored only at the peril of the country and the government of the day.

The administration of President Obasanjo was very conscious of the nature and importance of the public service as a determinant of success or failure of the administration in power. According to Wholey (1991), incentive structures are needed in government in order to achieve improvements in management and performance. As observed by Hyde (1991), major declines in a nation's annual rate of growth in productivity and loss of competitive position to other nations can alarm public leaders to spawn a host of new initiatives to increase productivity. It was in the realization of the strategic role of increased performance in the public service that the monetization of fringe benefits policy was adopted, as an aspect of the public sector reform.

The federal government policy on monetization in the public service across the nation became necessary due to the rising cost of governance, arising mostly from the benefits-in-kind that the various tiers of government have to provide to the public servants. 
Okwuosa (2004) observed that the policy is understood as the replacement of fringe benefits that were previously provided in kind, through additional monetary allowances, and the consequent withdrawal of government from the maintenance cost obligation that attended these benefits. Okwuosa further opined that the policy is in tune with trends widely practiced in private and public sectors in modern government.

These fringe benefits were carryover from the colonial era. The colonial government provided the colonial administrators free or highly subsidized residential accommodation, transportation facilities, gardeners, medical services, etc. Aluko (2005) noted that the expatriates did not have to pay for these amenities because they were entitled to hazard allowance by their home government. Aluko, however observed that they were few in number so that their total package was negligible when compared to the income which they extracted in favor of their home government. The monetization policy was intended to minimize waste, misuse and abuse of public facilities. To sum it up, the policy is intended to achieve efficiency and economy in government.

The monetization policy was given legal backing by the political, public and judicial office holders (Salaries and Allowances) Act 2002, which has now been extended to the civil servants. The law took effect from 1st July, 2003.

\subsection{Statement of Problem}

The monetization of fringe benefits was introduced with the intention of reducing waste and running cost of government, empowering the public servants to own houses, and ensuring effective service delivery. The monetization policy has generated some problems such as retrenchment of workers, apprehension of the civil servants as to whether it will lead to further retrenchment, inability of the workers to save enough money to buy their own houses due to the payment of the benefits in installments. The hasty payment for houses marked for sale by political officer holders and the ruling elites suggests that the policy is elitist. The money realized from the sale of houses and vehicles were either mismanaged or embezzled out rightly. Finally, the reversal of the policy especially as regards the sold houses and buying of cars for the ministers shows that there is confusion in the implementation of the policy. By implication, many civil servants especially the middle and low-income earners were not likely to buy the houses. Hence, the following hypotheses were formulated to guide the study:

a. Monetization policy has not reduced the running cost of government

b. Civil servants are not better off with the monetization of fringe benefits

c. The monetization of fringe benefits is elitist policy

\subsection{Objective of the Study}

The broad objective of this study is to critically appraise the working of Nigerian's monetization fringe benefits policy and identify problem areas. The specific objectives therefore are to:

Know whether monetization of fringe benefits has reduced running cost of government

Investigate the effect of monetization on the morale of civil servants;

Find out whether the civil servants were empowered to buy their own houses;

Find out the particular group the monetization policy favored most;

Identify the problems hindering effective implementation of the monetization policy.

\subsection{Review of Related Literature}

Monetization is the process of converting or establishing something into legal tender. It means converting items into money even if they are worthless but are difficult to make or acquire. In this sense therefore, monetization may also refer to exchanging securities, possessions, goods, and services for money. Ake (1981) defines it as an economic concept, meaning the presence of money as a means and medium of exchange. This is what we now call the modern monetary system or monetary economy. Money serving as a medium of exchange can by extension mean using money to pay for all forms of transactions and pensions, such as fringe benefits paid to public servants.

Monetization in the context of this study is the monetization of fringe benefits. McConnell (1987), defines, fringe benefits as the rewards other than wages that employees receive from their employers, which include persons, medical and dental insurance, paid vacations and sick leaves, etc.

Klein (1995) defines fringe benefits as a benefit given to an employee in addition to wage or salary. This may include non-contributory pensions, private health arrangements, subsidized meals, cars, accommodation, etc. Form the above definitions; we can conclude that fringe benefits in the Nigerian public services are those benefits that are given to the public servants in addition to their salaries such as car, accommodation, domestic servant allowances, etc. 
In a publication by the Federal Ministry of Information and National Orientation (2003) monetization of fringe benefits was defined as "the qualification in monetary terms of those fringe benefits which government used to provide for its workers as part of the conditions of service such as accommodation, transportation, utility, leave grant, etc".

The main components are:

(1) Residential accommodation:

a. $100 \%$ of annual basic salary to be paid en bloc annually as residential allocation, to enable the officers rent houses of their choice.

b. Government residential quarters across the country to be sold off by auction.

c. The present occupiers of residential quarters would be given the first option to purchase the houses, but at price of the highest bidder.

d. Government to provide site and service scheme in satellite towns nationwide in order to assist public servants, who would prefer to build their own houses acquire land.

(2) Furniture allocation:

a. 300 percent of annual basic salary will be paid in every four years in accordance with the provisions of the political, public and judicial office holders (Salary and Allowance) Act. 2002.

b. This allowance would be paid annually at the rate of $75 \%$, which amounts to $300 \%$ in four years.

(3) Motor vehicle loan and transport:

a. The government will no longer provide chauffeurs for public officers.

b. 350 percent of annual basic salary will be granted as motor vehicle loan.

c. Loan will be recovered within 6 years at 4 percent interest.

(4) Use of government vehicle

a. No new vehicle will be purchased by any ministry, extra ministerial department, and federal Agency or Parastatals.

b. A specific number of utility vehicles will be allowed each ministry or department. No ministry will exceed the number without prior approval of Mr. President.

c. Officers currently entitled to government vehicles would return them to Presidency for disposal or pooling in the Conference Vehicle Unit (CVU) as may be appropriate.

d. A committee will be set up to handle the issue of disposal of vehicles.

e. If there is a need to purchase a new vehicle by any ministry, extra-ministerial Department of Agency, a request shall be made to Mr. President for approval.

f. Provision of drivers to entitled officers would be monetized as follows:

(i) S.G.F/Minister/HOS-2 drivers=N239. 172 per annum.

(ii) Perm. Sec. -1 driver $=$ N11 119,586 per annum,

(iii) Director - I driver N119.586 per annum. The allowance will be the same with the current provision for domestic servants, i.e, total enrollment of an officer on grade level 03 step 8.

g. Service-wide staff buses will pool under the management of the office of the Head of the civil service of the federation. Any member of staff who utilizes the facility shall be made to pay at a rate equivalent to their transport allowance and funds so generated would be used for the maintenance and fuelling of the vehicle. This facility will be gradually withdrawn when the public transport service improves. On the fate of excess drivers in the system as a result of the new policy, the following steps were recommended.

h. Those with relevant and adequate qualifications would be retained and redeployed appropriately.

(i) Depending on the need, others will be deployed to drive staff buses under the officer of Head of the Civil Service of Federation.

(ii) Those that will not be deployable will be rationalized but to be assisted by the National Poverty Eradication Program under KEKE NAPEP Program.

(5) Medical allowance: 
Government has proposed the payment of $10 \%$ of an officer's annual basic salary as medical allowance.

(6) Other Allowance:

Leave grant, meal subsidy and entertainment allowances shall be paid to workers as earlier stated.

\subsection{Running cost of Government}

After independence, the indigenous high cadre public servants took over and continued to enjoy those fringe benefits. As time went on and with the increase in the number of high cadre public servants, the cost of providing these amenities to public servants became so huge vis-à-vis other provisions in the annual appropriations. Thus, little was left for funding capital projects by government. The problem was compounded when these benefits were largely not provided in the most cost effective manner, and were also highly abused by the Nigerian public servants. For example, instead of having one official car, some civil servants have as many as three official cars attached to them, some government officials transferred to Abuja still kept their houses (official quarters) in Lagos.

The provision of some of the fringe benefits has continued to consume enormous resources from the public purse. In addition, according to Aluko (2005), although the civil servants constitute about $20 \%$ of the population of Nigeria, to maintain them takes up to $60-70 \%$ of the Annual National budget expenditure. The then president of Nigeria, Chief Obasanjo (2003), in his inaugural address, stated that, "the cost of running government at all the levels currently gulps a disproportionate amount of our revenue"

There were other observed problems in the public service that made for the rising cost of government in Nigeria. First according to Jimoh (2007), is the increasing large number of workers entitled to fringe benefits (especially hosing, etc) that were being provided with allowances in lieu, as the capacities of available facilities were being over-stretched. As noted by Talba (2004) available records show that as at June 2003, only about $20 \%$ of Federal public servants lived in government quarters (either government-owned or rented), while the rest were paid rent allowance. This implies that those who were entitled to the fringe benefits of living in government-owned houses but could not be provided had the corresponding fringe benefits monetized already. Secondly, the cost of servicing the public service was taking over $60 \%$ of federal Recurrent Expenditures (Adegoroye, 2005).

Finally from the annual Report of CBN from 1996 to 2004, it could be seen that in 1996, the Federal Government's wage bill was about $33 \%$ of the federal recurrent expenditures reaching a peak of about $60 \%$ in 2000.

It is in reaction to the wastage, high cost of administration, and in search of efficiency and economy in government that the federal government sought for a way out, and monetization was chosen as a preferred option.

Okwosa (2004), noted that monetization of fringe benefits of public servants is a government policy, which aims at empowering the public servants financially so that they would henceforth take personal care of those things (benefits) that were hitherto taken care of by the government. In Nigeria, the Obasanjo-led administration introduced the policy in 2003, against the backdrop of rising cost of achieving the government business. The Revenue Mobilization Allocation and Fiscal Commission recommended the policy, when it observed that the nation devotes over $60 \%$ of its revenue to sustain recurrent expenditure. This development gave rise to a soul-searching moment for solution to the economic down-turn. Hence monetization provides the needed answer.

\subsection{The Thrust of the Monetization Policy}

The objectives of the policy of monetization according to both the Budget Circulars (2000) and the Secretary to the Government of Federation (2003) are as follows:

(i) to reduce waste, misuse and abuse of public resources.

(ii) to change government's budgetary profile by reduction of spirally overhead cost and conservation of more funds for capital expenditure.

(iii) to reduce capital cost as well as maintenance and running cost.

(iv) to reduce the rent burden on government

(v) to assist and encourage public servants to own personal houses

(vi) to encourage maintenance culture and discipline among public servants

(vii) to save cost and money for the government.

The major aim of the policy is to positively impact on our national value system, especially in government planning, budgeting and discipline. 


\subsection{Theoretical Framework}

This paper takes its bearing on elite theory. According to Dye and Zeigler (1981), public policy may be viewed as the preferences and values of governing elite.

Elite theory suggests that the people are apathetic and ill-informed about public policy, that the elites actually shape mass opinion on policy questions more than masses shape elite opinion (Dye, 1981). Public officials and administrators merely carry out the policies decide upon by the elite. Elite theory can be summarized briefly as follows according to Dye (1981):

(1) Society is divided into the few who have power and the many who do not. Only a small number of persons allocate values for society, the messes do not decide public policy.

(2) The few who govern are not typical of the masses who are governed. Elites are drawn disproportionately from the upper socio-economic strata of society.

(3) The movement of non-elites to elite positions must be slow and continuous to maintain stability and avoid revolution.

(4) Public policy does not reflect demands of the masses but rather the prevailing values of the elite. Changes in public policy will be incremental rather than revolutionary.

(5) Elites influence masses more than masses influence elites.

\subsection{The Relevance of the Theory to the Study}

It is our contention that the monetization policy is elite policy. However elitism does not mean that public policy will be entirely against welfare, but only that the responsibility for mass welfare rests upon the shoulders of elites. The following will help buttress our earlier contention that the monetization policy is elitist in both character and conduct.

a. The Apo legislative quarters, and residential quarters of top security organizations Heads were sold to them (the occupiers) who are among the elite. We agree with Okon (2005), that the United African Company (UAC) Property Development Company - a prime property manager-that bought the 1004 Housing Estate is to the detriment of the occupiers (masses) and in contravention of the government earlier statement, that the occupiers would be considered first. The UAC is among the cronies of the ruling elites.

b. The other houses sold were too costly for the public servants and were bought by the same elites who could afford the prices. The full payment of monetization benefits to the political office holders (the ruling elites) shows that the policy favored the elites more. The benefits of the other civil servants were paid in installments.

c. Eric Moore Towers estate was purchased for a paltry sum of N40 million, a price which compelled the occupant to clamor to buy the estate at N240 million (Guardian Feb, 2004).

$\mathrm{d}$. The disengagement of the so-called non-deployable drivers shows that the elites influence the masses more than the masses influence them, in view of the fact that there were no objective criteria to show that those drivers were not deployable.

e. The policy reversal of buying cars at least for the ministers and permanent secretaries agrees with the proposition that elite interest prevails over that of the masses. Moreover, it means that they have eaten their cakes (Monetization benefits) and are having them back (Admelokun, 2008).

f. The payment in installments of monetization benefits to other workers ensures that the masses will not be able to have reasonable amount en bloc to provide houses or cars of their own.

\section{Methodology}

\subsection{Research Design}

The survey research method was used to gather data simply because of its usability with large sample as was the case with the present study where $\mathrm{N}=100$. The study is significantly interpretative because it focuses on qualitative and quantitative data.

\subsection{Sample}

Four hundred respondents formed the sample for the study. The sample had diversity in terms of rank, gender, experience, age and post among other variables. 


\subsection{Instrumentation}

Questionnaire items were used to source data from the respondents. The respondents understood the items sought with regards to monetization of fringe benefits policy in Nigeria as were conceptualized in the literature review. The pilot test of the questionnaire was very high by raters with in-depth experience in the use of the instrument for research purposes. Even though it was not easy to get to all the respondents by the researchers owing to the problems of time and space, $95 \%$ of the administered questionnaires were returned. For the fact that the subject matter interested every civil servant, and coupled with the fact that the questionnaires were self explanatory and all respondents were literate the issue of non-return bias was eliminated. Structured oral interviews were conducted with selected heads of the three categories of respondents that entered the sample as a follow-up to the questionnaire in order to glean the subtle aspects that questionnaire items could not adequately elicit. The interviews concentrated mainly on the respondents' justification for particular response options to questionnaire items.

\subsection{Data Presentation and Analysis}

Responses that were relevant to the objectives and hypotheses formulated were used. The method applied in the analysis was difference in proportion and in testing the hypotheses formulated; the chi-square $\left(\chi^{2}\right)$ was used.

\subsection{Presentation and Analysis of Data}

Test statistics of frequency and percentage were used to test the questionnaire while chi-square was used to test the validity of the hypotheses.

$$
\text { Chi-square: } \chi^{2}=\frac{\left(0-\mathrm{E}^{2}\right)}{\mathrm{E}}
$$

Where $0=$ observed frequency, $\mathrm{E}=$ expected frequency.

The level of significant is $5 \%$

Chi-square was used because the population involved more than two proportions.

\section{Test of hypothesis}

\subsection{Hypothesis One}

$\mathrm{H}_{0}$ : Civil Servants are not better off with the monetization of fringe benefits policy.

$\mathrm{H}_{1}$ : Civil Servants are better off with the monetization of fringe benefits policy.

We shall apply chi-square:

$$
\chi^{2}=\frac{\sum\left(\mathrm{f}_{0}-\mathrm{f}_{\mathrm{e}}\right)}{\mathrm{f}_{\mathrm{e}}}
$$

where $\chi^{2}=$ chi-square, $\mathrm{f}_{\mathrm{e}}=\mathrm{f}_{0}$ : observed value, $\mathrm{f}_{\mathrm{e}}$ : expected value, 0.05 level of significances.

\begin{tabular}{|c|c|c|c|c|c|}
\hline No & Items & Agree & Disagree & Undecided & Total \\
\hline 8 & $\begin{array}{l}\text { Monetization has increased your take } \\
\text { home package }\end{array}$ & 240 & 105 & 16 & 361 \\
\hline 9 & $\begin{array}{l}\text { Monetization has improved the living } \\
\text { standards of workers }\end{array}$ & 132 & 218 & 11 & 361 \\
\hline 10 & $\begin{array}{c}\text { Monetization has boosted the moral of } \\
\text { workers }\end{array}$ & 218 & 120 & 23 & 361 \\
\hline \multirow[t]{2}{*}{11} & $\begin{array}{l}\text { Monetization has empowered civil } \\
\text { servants }\end{array}$ & 78 & 249 & 24 & 361 \\
\hline & Total & 668 & 692 & 84 & 1444 \\
\hline
\end{tabular}

Table 1: Effects of Monetization of Fringe Benefits on Workers

To find the expected frequency, the following formula is used: 


$$
f_{e}=\frac{R T \times C T}{G T}
$$

Where E: Expected frequency, RT=Row Total, CT=Column, GT=Grant Total.

Calculation of Expected Frequency (fe):

$$
\begin{gathered}
\text { Disagree }(\mathrm{DS})=\frac{361 \times 668}{1444}=167 \\
\text { Agree }(\mathrm{A})=\frac{361 \times 692}{1444}=173 \\
\text { Undecided (UD) }=\frac{361 \times 84}{1444}=21
\end{gathered}
$$

Table 2. Using substitution to calculate chi-square

\begin{tabular}{cccccc}
\hline Alternatives & $\mathrm{f}_{0}$ & $\mathrm{f}_{\mathrm{e}}$ & $\mathrm{f}_{0}-\mathrm{f}_{\mathrm{e}}$ & $\left(\mathrm{f}_{0}-\mathrm{f}_{\mathrm{e}}\right)^{2}$ & $\frac{\left(\mathrm{f}_{0}-\mathrm{f}_{\mathrm{e}}\right)^{2}}{\mathrm{f}_{\mathrm{e}}}$ \\
\hline A & 240 & 167 & 73 & 5329 & 31.91 \\
DS & 105 & 173 & -68 & 4624 & 26.73 \\
UD & 16 & 21 & -5 & 25 & 1.19 \\
A & 132 & 167 & -35 & 1225 & 7.33 \\
DS & 218 & 173 & -45 & 2025 & 11.70 \\
UD & 11 & 21 & -10 & 100 & 4.76 \\
A & 218 & 167 & -51 & 2601 & 12,58 \\
DS & 120 & 173 & -53 & 2809 & 16.23 \\
UD & 23 & 21 & 2 & 4 & 0.19 \\
A & 78 & 167 & -89 & 9721 & 47.43 \\
DS & 249 & 173 & 76 & 5776 & 33.38 \\
UD & 34 & 21 & 13 & 169 & 4.97 \\
\hline
\end{tabular}

Calculated $\chi^{2}=162.43 . \mathrm{DF}=(\mathrm{r}-1) \times(\mathrm{c}-1)=(4-1) \times(3-1)=2 \times 2=4$.

Under 4 degree of freedom at 0.05 level of significance chi-square $=9.48$ from the table 1 above.

Decision Rule: Reject the null hypothesis and accept the alternative hypothesis, if chi-square $\left(\chi^{2}\right)$ calculated value is greater than chi-square value from the table, otherwise accept it. Therefore, null hypothesis is rejected since the calculated chi-square is greater. This means that civil servants are better off with the monetization of fringe benefits policy.

Using the formula $f_{e}=\frac{R T \times C T}{G T}$

For Agree $(\mathrm{A})=\frac{581 \times 361}{1083}=194$

$\operatorname{Agree}(\mathrm{A})=\frac{475 \times 361}{1083}=150$

For undecided (UD) $=\frac{27 \times 361}{1083}=9$ 
Chi-Square $\chi^{2}=\left(\mathrm{f}_{0}-\mathrm{f}_{\mathrm{e}}\right)^{2}$

Table 3. Relationship of the Monetization of Fringe Benefits and Running Cost of government

\begin{tabular}{cccccc}
\hline No & Igree & Disagree & Undecided & Total \\
\hline 14 & $\begin{array}{c}\text { Monetization has reduced the running } \\
\text { cost of government }\end{array}$ & 230 & 115 & 16 & 361 \\
$\begin{array}{c}\text { Monetization has reduced waste and } \\
\text { abuse in the use of government } \\
\text { facilities }\end{array}$ & 235 & 120 & 6 & 261 \\
$\quad \begin{array}{c}\text { The large amount used to implement } \\
\text { the policy outweighs the benefits } \\
\text { Total }\end{array}$ & 116 & 240 & 5 & 361 \\
& 581 & 475 & 27 & 1083 \\
\hline
\end{tabular}

Table 4. Calculation of chi-square using substitution

\begin{tabular}{cccccc}
\hline Alternatives & $\mathrm{f}_{0}$ & $\mathrm{f}_{\mathrm{e}}$ & $\mathrm{f}_{0}-\mathrm{f}_{\mathrm{e}}$ & $\left(\mathrm{f}_{0}-\mathrm{f}_{\mathrm{e}}\right)^{2}$ & $\frac{\left(\mathrm{f}_{0}-\mathrm{f}_{\mathrm{e}}\right)^{2}}{\mathrm{f}_{\mathrm{e}}}$ \\
\hline A & 230 & 194 & 36 & 1296 & 6.68 \\
DS & 115 & 150 & -35 & 1225 & 8.16 \\
UD & 16 & 9 & 7 & 49 & 5.44 \\
A & 235 & 194 & 41 & 1681 & 8.66 \\
DS & 120 & 150 & -30 & 900 & 6.00 \\
UD & 6 & 9 & -3 & 9 & 1.00 \\
A & 116 & 194 & 078 & 6084 & 31.36 \\
DS & 240 & 150 & 90 & 8100 & 54.00 \\
UD & 5 & 9 & -4 & 16 & 1.77 \\
\hline
\end{tabular}

Calculated chi-square is 123.07

First, the degree of freedom is DF. DF $=(\mathrm{r}-1) \times(\mathrm{c}-1)=(3-1) \times(3-1)=2 \times 2=4$

Under 4 degree of freedom at 0.05 level of significance, chi-square table value is 9.48 .

Decision: The null hypothesis is rejected and alternate accepted, since the calculated chi-square is greater than the chi-square from the table. Thus, it means that monetization of fringe benefits has reduced the running cost of government.

\subsection{Hypothesis Three}

$\mathrm{H}_{0}$ : Monetization policy is not an elite policy

$\mathrm{H}_{1}$ : Monetization policy is an elite policy

The expected frequency is calculated by using $\mathrm{f}_{\mathrm{e}}=\frac{\mathrm{RT} \times \mathrm{CT}}{\mathrm{GT}}$

$\mathrm{RT}=361, \mathrm{CT}=675,339$ and $69, \mathrm{GT}=1083$

$$
\begin{gathered}
\text { Agree }(A)=\frac{675 \times 361}{1083}=225 \\
\text { Disagree (DS) }=\frac{339 \times 361}{1083}=113
\end{gathered}
$$




$$
\text { Undecided (UD) }=\frac{69 \times 361}{1083}=23
$$

Table 5. Nature of Monetization of Fringe Benefits Policy

\begin{tabular}{cccccc}
\hline No & Items & Agree & Disagree & Undecided & Total \\
\hline 17 & $\begin{array}{c}\text { The political office holders (elites) are } \\
\text { the major beneficiaries of } \\
\text { monetization policy }\end{array}$ & 229 & 98 & 34 & 361 \\
$\begin{array}{c}\text { The monetization of fringe benefits } \\
18\end{array}$ & policy is mainly to serve the interest of \\
the elites. & 236 & 103 & 22 & 361 \\
19 & $\begin{array}{c}\text { The political office holders (elites) } \\
\text { were better empowered to own houses } \\
\text { Total }\end{array}$ & 210 & 138 & 13 & 361 \\
\hline
\end{tabular}

Table 6. Calculation of chi-square $\chi^{2}$

\begin{tabular}{cccccc}
\hline Alternatives & $\mathrm{f}_{0}$ & $\mathrm{f}_{\mathrm{e}}$ & $\mathrm{f}_{0}-\mathrm{f}_{\mathrm{e}}$ & $\left(\mathrm{f}_{0}-\mathrm{f}_{\mathrm{e}}\right)^{2}$ & $\frac{\left(\mathrm{f}_{0}-\mathrm{f}_{\mathrm{e}}\right)^{2}}{\mathrm{f}_{\mathrm{e}}}$ \\
\hline A & 229 & 225 & 4 & 16 & 0.07 \\
DS & 98 & 113 & -15 & 225 & 1.99 \\
UD & 34 & 23 & 11 & 121 & 5.26 \\
A & 236 & 225 & 11 & 121 & 0.53 \\
DS & 103 & 113 & -10 & 100 & 0.88 \\
UD & 22 & 23 & -1 & 1 & 0.04 \\
A & 210 & 225 & -15 & 225 & 1.00 \\
DS & 138 & 113 & 25 & 625 & 5.53 \\
UD & 13 & 23 & -10 & 100 & 4.34 \\
\hline
\end{tabular}

At $5 \%$ level of significance, degree of freedom $(\mathrm{DF})=(\mathrm{r}-1) \times(\mathrm{c}-1)=(3-1) \times(3-1)=2 \times 2=4$ (from the table) Under the degree of freedom at 0.05 level of significance, chi-square table value is $=948$.

Decision Rule: Reject the Null hypothesis if the calculated $\chi^{2}$ value is grater than the table value. Therefore the alternate hypothesis is accepted, which mean that the monetization of fringe benefits policy is elitist.

\section{Summary of Findings}

The following findings were made:

a. The civil savants are better off with the implementation of monetization of fringe benefits policy in Nigeria.

b. The implementation of the monetization of fringe benefits policy has reduced the running cost of federal government of Nigeria.

c. The monetization of fringe benefits policy is elitist in approach in Nigeria.

d. The implementation of monetization of fringe benefits policy in Nigeria has generated some unintended consequences due to reversal of some aspects of the policy.

e. The Monetization of fringe benefits policy has not enabled the middle and lower cadres' civil savants to purchase houses from the ones sold, but rather favored the ruling elites and political office holders. 


\section{Recommendations}

Based on our findings the following recommendations are made:

a. Efforts should be made to address the sever unintended consequences generated by the reversal of some aspects of monetization of fringe benefits policy. This is to ensure equity and give some sense of belonging to the groups adversely affected by the poor implementation of the policy.

b. The government houses sold to the legislators, ruling elites, top civil and public serving officers, etc, at ridiculous prices should be revoked and recovered from them.

c. The payment of the total yearly fringe benefits to workers would really empower them to do something tangible with the money as against the adopted install mental payments. The install mental payment is also one of the reversals of the policy at the implementation stage.

d. In view of the enormous benefits accruable from the monetization of fringe benefits policy if properly implemented, we recommend its adoption by states and local governments in Nigeria, and all tiers of governments of under-developed and developing countries of the world that have not experimented it. They should adopt direct implementation method and ensure adequate analysis of the implementation machinery, and provide measures that will cushion its negative effects to avoid Nigeria's costly mistakes.

\section{Conclusion}

Having explored the implementation and implications of monetization of fringe benefits policy in Nigeria's federal civil service, we hereby concluded that the policy is a veritable instrument in reducing cost and waste in government. However, the way and manner the policy has been implemented so for calls for serious restructuring of the implementation machinery; otherwise it shall generate some huddles and serve only the interest of the ruling elites and political class. It is also our conviction that with proper implementation and review of the policy, benefits may accrue to all and sundry.

\section{References}

Adamolekun, L. (2008, January 14). Policy Reversals and Policy Making - an Update. National Vanguard.

Adegoroye, G. (2005). Public Service Reforms: Implications for Ekiti State under Current Democratic Administration. Ekiti State Public Lecture. Ado-Ekiti: Ekiti State Government.

Ake, C. (1981). A Political Economy of Africa. London: Longman.

Alkali, A. U., Sambo, E., \& Musa P. A. (2005). The Effects of Monetization Policy on Workers Productivity. International Journal of Social and Policy, 3(1), 27-38. Development Universal Consortia, Nigeria.

Aluko, M. E. (2003). Monetization of Fringe Benefits in the Nigeria Public-Service. Retrieved from http://www.dawodu.com/aluko61.htm.

Anderson, J. (1975). Public Policy and Political in America. New York: Praeger Publishers.

Anumudu, C. N., \& Anumudu, E. N. (2005). Applied Statistics for Social and Management Sciences. Nsukka: Great AP Express Publishers Ltd.

Denhardt, R. B. (2002). Managing Human Behaviour in Public \& Nonprofit organizations. U. K. Sage Publications.

Dye, T. R. (1981). Understanding Public Policy. Englewood: Prentice-Hall Inc.

Dye, T. R., \& Zeigler, H. (1981). The Irony of Democracy (5th ed). California: Wadsworth.

Ekaette, U. T. (2003). Waste Control: Discipline, Monetization of Benefits. A Paper Delivered by the Secretary to the State Govenrment of the Federation at the Retreat for Ministers and Permanent Secretaries at the NICON HILTON, Hotel, Abuja: July 18.

Federal Ministry of Information and National Orientation. (2003). The Obasanjo Reforms on Monetization.

FGN. (2006). Monetization Policy. Retrieved from http/www.fmf.gov.ng. Abuja: Federal Ministry of Finance.

Guardian. (2004, February 12). Sale of Government Houses. Editorial.

Hyde, A. C. (1991). Productivity Management for Public Sector Organizations. In J. M. Shafritz (Ed.), Public Management: The Essential Readings. Chicago: Nelson-Hall Publishers.

Jimoh, A. (2007). Monetization of Fringe Benefits of Public Servants. In H. Saliu (Ed.), Nigeria's Reform Programme: Issues and Challenges. Ibadan: Vantage Publishers Ltd. 
Jones, C. O. (1977). An Introduction to the Study of Public Policy. California: Duxbury Press.

Klein, G. (1995). Dictionary of Banking. London: Financial Time Pitman Publishing.

McConnell, C. R. (1987). Economics: Principles, Problems and Policies. New York: McGraw-Hill Books Company.

McNabb, D. E. (2004). Research Methods for Political Science, Quantitative and Qualitative Methods. New Delhi: Prentice Hall.

Okon, E. (2005). Monetization Policy in the Nigerian Public Service: A Critical Appraisal of Obasanjo's Public Services Reform. International Journal of Social and Policy, 2(3), 178-195. Development Universal Consortium Nigeria.

Okwuosa, A. (2004). Monetization of Fringe Benefits for Public Officers And its Implications for the Manpower Budget of the Federal Civil Service. A Paper Presented at a Training Workshop on Effective Manpower Planning in the Federal Civil Service. Confluence Beach Hotel Lokoja July $7-10$.

Philip, D. (1985). Essentials of the 1988 Civil Service Reforms in Nigeria. Nigerian Institute of Social and Economic Research (NISER), Monograph Series No. 2. Ibadan.

SGF Circular. (2003, July 27). Monetization of Fringe Benefits in the Federal Public Service Circular, 1-6.

Stoner, J. A. F., Freeman, R. E., \& Gilbert, D. R. (2005). Management. India: Pearson education Ltd.

Talba, M. I. (2004). Building Effective Government. Retrieved February 27, 2004, from $\mathrm{http} / \mathrm{www}$. Victoria.ac.nz/commonwealthseminar/paper/2004

Wholey, I. S. (1991). Creating Incentives for Improved Government Performance. In J. M. Shafritz (Ed.), Public Management: The Essential Readings. Chicago: Nelson-Hall Publishers. 